\title{
2 Conceptual Choices and Theoretical Framework
}

\author{
Eventful history, interaction dynamics, and discursive \\ arenas
}

\begin{abstract}
This chapter outlines the conceptual choices and develops the theoretical framework of this inquiry. This includes a micro-level approach to the study of contention, an interactionist framework of analysis, and special attention to the discursive arena of contentious politics. It introduces the idea of social mobilization as populations of contentious events by compound players who interact with their counterparts in complex protest arenas. The emergence of political subjectivities, as well as players' strategic choices on alliance-building, mobilization, and employed tactical repertoires, are all embedded in and contingent on these interactions. This chapter illustrates how discourse theory, by accounting for both linguistic meaning and the material event, can contribute to developing the concept of protest arenas further by theorizing the discursive layers of interaction that accompany contentious struggles.
\end{abstract}

Keywords: eventful protest, players, arenas, discourse theory, transformative events

With its focus on symbolic interaction and contested interpretations of contentious politics, this book deals primarily with the discursive interactions that accompany and shape both, state repression and social protests. A discourse is defined here as "a particular way of representing certain aspects of the world, whether physical, social or psychological" (Rear \& Jones, 2013, p. 375). About physical interactions, such as distinct protest gatherings or the repressive measures taken by security forces on a specific date against the people in the streets, there are always different representations that

Grimm, Jannis Julien, Contested Legitimacies: Repression and Revolt in Post-Revolutionary Egypt. Amsterdam: Amsterdam University Press 2022 DOI: $10.5117 / 978946372265^{\circ}$ _CHO2 
compete for meaning. This has been true for Egypt ever since the outbreak of the political struggle in 2011, as Khaled Abdalla (2016) illustrates in his discussion of the shifting fault lines of the revolution:

Is 25 January the anniversary of the revolution, or a day commemorating the police? Did we have two revolutions? Were the events of June 30 , 2013, a revolution or a coup? Can the Muslim Brotherhood's program be considered "secular"? Who killed who on what day? Who is conspiring to destabilize the country? Is it our duty to obey or to challenge? (p. 37)

How these questions are answered by individuals is, and always was, more than a question of representation. According to Pratt (2015), the struggles over the meaning and objectives of the January 25 Revolution represent "struggles over 'the hearts and minds' of the Egyptian people and the definition of the future polity" (p. 48). Due to language's constitutive aspects, the meanings attached to material events have immediate and tangible real-world consequences. By constituting the boundaries of responses by contending players, they are significant for the course of events during phases of contention. Discourses and the physical events they signify are thus a two-way street, or as Marianne Jørgensen and Louise Phillips (2002) stress, "discourse is a form of social practice which both constitutes the social world and is constituted by other social practices" (p. 61).

The theoretical framework presented in this chapter builds on these considerations. It bridges the discourse theoretical research tradition and the contentious politics research program. It subscribes to the idea of social mobilization as a population of collective action events, and thus to a "constructivist" approach to social movements. Based on this thought, it is claimed that political players, such as social movements or authoritarian regimes, are not static and uniform actors, endowed with certain features and traits that can be inferred based on their ideology, culture, or religious affiliation. Instead, they are complex compound and (inter-)active social players and themselves the products of a contingent social context.

Procedural and interactional approaches have attempted to make sense of this relation by investigating the relational subjectivation processes within different social arenas that give rise to compound players such as social movements that challenge the status quo. Foregrounding the short-term effects of the interactions between regimes and their contenders, above all scholars of political violence and repression (a.o., Della Porta, 2014b; Earl \& Soule, 2010; Francisco, 2004; Hess \& Martin, 2006; Jasper \& Poulsen, 1995; McCarthy \& McPhail, 2005) first illustrated how windows for mobilization 
were often situational, and emerge spontaneously and unexpectedly from contentious interaction. Hanspeter Kriesi (2004), for instance, noted that "episodes of contentious interaction are likely to modify the relevant configuration of actors and, thus, to change the specific opportunities for future options for collective action" (p. 79). In a similar vein, Della Porta (2011) talks about the "eventfulness" of protest to describe how social movements can create opportunities for themselves or other players that follow. ${ }^{1}$

The Arab Spring was a prime example of this generative process. It demonstrated the necessity to move beyond structuralist and taxonomic accounts in what Lawson (2016) has referred to as the "fourth generation" of revolutionary theory. Like the collapse of the Soviet regime in 1989, the Arab Spring is often portrayed as a "structurally overdetermined drama" (Beissinger, 2009, p. 335). But actually, it depended on countless acts of contention whose outcomes were hardly predetermined, as each event altered the "constellation of possibilities in the future" (Alimi \& Meyer, 2011, p. 477). Della Porta (2014a, pp. 29-32) has drawn parallels between this eventful character of the upheaval in the Arab World and the popular uprisings in the GDR and former Czechoslovakia: It was in their dynamic interaction that innovative coalitions of contenders produced relations that favored mobilization and transformation. In both protest waves, she notes, social mobilization "fueled itself: it did not so much respond to emerging political opportunities as it created and broadened them in the struggle" (Della Porta, 2014a, p. 191).

Her comparative historical approach to the analysis of the Arab Uprisings as a process of democratization from below is one of the few attempts to establish bridges between the disciplinary perspectives of transition and democratization studies, on the one hand, and those of social movement scholars on the other. The prognosis of democratization in Egypt may have been disproven by the bleak political reality of a counterrevolution and a protest-driven democratic roll-back from below. The merit of Della Porta's

1 The work of both authors reverberates William Sewell's conception of an eventful temporality of protest, which highlights how social structures, thought durable and resilient, can effectively be transformed through collective agency. Sewell recognized a necessity to relocate the focus of historical sociology to the analysis of events, making a head start with his study of the publication of Abbé Sieyes' Qu'est que c'est le tiers état? and the storming of the Bastille in 1789 - two events at the outset of a most decisive contentious episode in European history (see Sewell, 1996a). In a later essay with Doug McAdam (2001), he identifies four different temporal rhythms that each grasped different aspects of social movement and revolution: 1) cultural epochs/master templates; 2) long-term changes that destabilize existing power relations; 3 ) protest cycles, which denote the temporally narrow and most active phase of social movements; and 4) transformative events, unique moments of collective creativity. 
analysis, however, lies in her dynamic conception of contentious politics as more than a context variable for elite decision-making. She and others have stressed how it was effectively a sequence of responsive and interactive events that had a transformative impact on mobilization in Egypt. These dynamics provided the trigger for translating long-existing structural conditions for cross-class and cross-ideological mobilization into effective collective action coalitions.

In a similar vein, several more recent studies of the Arab Spring aftermath have underscored that the puzzle of successful mass mobilization amid stable authoritarianism can be solved only by adopting a procedural and relational perspective and by focusing on micro-level dynamics, rather than macro-level structural shifts (e.g., Grimm \& Harders, 2018; Harders \& König, 2013; Jasper \& Volpi, 2018; Volpi \& Clark, 2019; Weipert-Fenner, 2021). After all, what is conventionally understood as political opportunity structures underwent little change at the forefront of the 2011 uprisings. Neither the cohesion of regime elites, nor the permeability of their polities, nor the capacities of their coercive apparatuses had experienced significant change. But during the 18 days of Tahrir, authorities, and contenders changed the perception about these structures through their interactions, thus creating new openings themselves.

\section{Players and Arenas}

Few authors have been more vocal in their critique of an exclusive focus on the macro conditions of social change than Jeff Goodwin and James Jasper. In their now seminal critique of the structural reductionism inherent in the political opportunities approach Goodwin and Jasper (1999) noted that political process theory, despite its inherent tautological bias, had become hegemonic in the field of social movement studies to the extent that analyses increasingly portrayed political opportunities as the necessary and sufficient conditions for mobilizations while failing to assess how individuals recognized, realized or created these opportunities. Recent contributions to the political opportunities paradigm may have taken the constructed nature of opportunities more seriously (see Giugni, 2009; Koopmans \& Olzak, 2004). However, they equally fell short of accounting for the volatility of social interaction and the contingency of its effects, mostly black-boxing public discourse as a mere resonance chamber.

Jim Jasper's later works then attempted to overcome the stalemate between structural and cultural studies of protests (Jasper, 2015a, p. 9). In two 
complementary edited volumes, he and his collaborators offered an attempt at theoretical bridge building by focusing on the strategic interactions that accompany and define situations of mobilization and contestation (see Duyvendak \& Jasper, 2015; Jasper \& Duyvendak, 2015). ${ }^{2}$ Three elements are central to this approach: players, arenas, and strategic interaction. Players can be thought of as individuals or groups of individuals who engage strategically with each other for specific purposes (Jasper, 2015b, p. 1off.). These purposes may vary among different factions of one compound player and they also vary over time. Jasper refers to the different circumstances and places where players interact as arenas thus taking up a Latin term that is usually employed to literally or metaphorically designate a combative stage that is designed to accommodate a multitude of spectators. According to Jasper, it is by engaging each other in such arenas that different actors become political players in the first place.

Beyond constituting merely a physical space, arenas can be thought of as sets of rules, norms, and resources that allow for the interaction of several individual or compound actors (Jasper, 2015b, p. 14f.). Jasper and Duyvendak prefer the metaphor of the arena over the resembling term "field" used by a range of other approaches that aim to balance the tendencies in sociological theory toward either structural determinism or an exclusive focus on contingency and agency, the "agency-structure behemoth" (McGarry et al., 2016, p. 635), and to define a middle ground between micro and macro scales of analysis (Bourdieu, 1993; DiMaggio \& Powell, 1983; Fligstein \& McAdam, 2015; Martin, 2003). One of the reasons for this is that they aim to distance themselves from notions of the field as an epistemic construct. For Jasper and Duyvendak, arenas are not merely imagined and constructed by the researcher in the process of data gathering and analysis. Instead, they are built by the interacting players themselves. For social scientists this means that they can "take a seat" in them and observe the interactions, such as when watching political talk shows on $\mathrm{TV}$, attending court sessions, or following debates on Twitter. In other words:

Arenas help stabilize chains of interactions by providing physical constraints, formal rules, and informal traditions. They offer places to sit or

2 The two editions engage in a division of labor, of sorts: While Players and Arenas analyses a multitude of social players, such as movement factions, foundations, companies, trade unions, and intellectuals, Breaking Down the State centers mainly on the different arenas of the state, including a.o. courts, political parties, police, military, and international organizations, such as the United Nations. 
stand, to observe or participate. They have transmission and recording devices to preserve the actions and decisions or to convey them to audiences not physically present. Their lighting and acoustics also shape the actions. (Jasper, 2018, p. 165)

Just like players, arenas are dynamic and malleable. They are always "emerging, changing, and recombining" (Jasper, 2015b, p. 13). Their transformative potential stems from the fact that rules and norms are constantly being strategically interpreted, contested, ignored, and broken. These interactions are part of the third conceptual pillar which, building on Goffmann (1986) and Blumer (2009), describes the strategic and culturally mediated interaction dynamics of players and arenas. These dynamics create, define, and change actors, arenas, and the entire social world. Strategy, in this context, denotes all conscious efforts by individual or compound actors to "get their way" (Jasper, 2008), that is, to force, convince or compel other players to do what they want them to do.

With a view to contentious politics, this model naturally begs the question of whether social movements and their counterparts should be conceived of as players or as arenas? The answer is both: According to Duyvendak and Jasper, in empirical reality, social movements (as well as states) often claim (or are attributed) a high level of internal coherence and unity. This unity represents a "necessary fiction" (Jasper, 2015b, p. 14) and can be explained through the rules of antagonist subject formation discussed in depth later in this chapter. But factually it often does not exist. Instead, players are usually highly heterogeneous, dynamic, and overlapping. Additionally, they often become arenas for social conflict or coordination themselves (see Polletta \& Kretschmer, 2015). They are thus arenas themselves but engage as players with a larger social theater.

The advantage in conceiving of movements through these lenses lies in the ability to capture also processes of mobilization that do not conform to the classical image of a social movement organization engaging in a campaign. Furthermore, a players-arenas perspective avoids homogenizing contentious actors by investigating them through essentialist analytical categories (like the youth, the workers, the Islamists, etc.). These categories often invoke a certain historical agency (e.g., of the working class in revolutions) that may not be empirically warranted for the investigated case. Moreover, in empirical reality, camps are rarely static or strictly demarcated. Especially broad mass mobilizations are better understood as "assemblages of diverse people and groups that in an exceptional moment come to apprehend a common goal" (Schwedler \& Harris, 2016, p. 4) than as social movements 
with discernible boundaries, memberships, and clear cut distinctions. As Goodwin, Jasper, and Khattra (1999, p. 31) stressed, "A social movement does not simply presuppose, but is itself an expression of the associated activities of some group or field of actors" (p. 31).

Accordingly, a methodological perspective on the individual (and its decisions and micro-interactions) should be at the basis of inquiries into macro-processes of change. Social movements are central to such change. But they must be understood as compound players composed of countless individuals who are driven not only by idiosyncratic interest or different layers of "Zweckrationalität" but also by emotions, urges, affective commitments, and long-forged moral identities (Jasper, 2018, p. 4ff.; see also Polletta \& Kretschmer, 2015, p. 47). The same holds for structural categories, such as class or ideology. While not denying the relevance of class or identity politics in determining the course of contentious politics, these phenomena are better understood as symptoms of subjectivation processes that are rooted in the reproduction of historical relations - hence, in players' interactions, rather than some essentialist substructure of the social (Bourdieu, 1987; Wacquant, 2019; see also Della Porta \& Atak, 2017, p. 37).

The analyses in this book build on these considerations. In my narration of Egypt's post-revolutionary history, I subscribe to a view of protest cycles as the results of complex relations between autonomous individuals on a micro-level. Accordingly, the analytical focus lies on the strategic, that is, goal-oriented practices of human interaction (Jasper, 2015b, p. 19). The trajectory of the investigated protest cycles is not ascribed to structural conditions or the idiosyncratic features of given movements, such as their supposedly static ideological predisposition. Instead, protest cycles are viewed as products of complex interactions between authorities, coalition partners, competitors, and the public. These interactions are captured and observed symptomatically through the investigation of events, which provide moments of structuring that harmonize the individual struggles of different players.

\section{Contentious Interaction at Critical Junctures}

As conceived by McAdam and Sewell (2001), events may be thought of as "unique happenings, full of accident, contingency, and sudden, unexpected transformations" (pp. 100-102). They are "punctual and discontinuous rather than cyclical, linear, or continuous" (p. 102). McAdam and Sewell find commonalities between events during revolutionary times and the conventional 
temporal registers of social movements. But they are careful to underscore the importance of a few historic events, lamenting that sociological analysts had, so far, left their analysis to historians. Events such as the taking of the Bastille explored by McAdam and Sewell exert a transformative effect on people as they created "hitherto unimagined categories of political action" (Tarrow, 2001, p. 106). It is during these events that we can observe "concentrated moments of political and cultural creativity when the logic of historical development is reconfigured by human action" (McAdam \& Sewell, 2001, p. 112).

The authors capture these crucial turning points in the history of social movements in their notion of transformative events. The idea of a transformative event is that of a short-term temporality that opens a new temporal register wherein "a new future becomes possible, a new founding" (Schwedler, 2016). Time becomes fateful because it comes to be seen as "irreversible, in the sense that an action, once taken, or an event, once experienced, cannot be obliterated" (Sewell, 2009, p. 6). They cannot be undone and unthought, propelling an impression of liminality. Donatella Della Porta and Kivanc Atac (2017) have related this experienced liminality, which is characterized by political contingency and a high level of uncertainty among social players, to the notion of critical junctures. Critical junctures are structurally undetermined in that their impact highly depends on how players perceive the exceptional movement and adjust their course of action accordingly. Rather than creating rigid path dependencies, critical junctures usually expand the horizon of possibilities and thus the range of plausible action choices (Della Porta \& Atak, 2017, p. 32f.). As Della Porta (2014b) writes elsewhere, the exceptional moment is often seen "as requiring exceptional commitment" (p. 178), which can catalyze innovation and lead to the emergence of wholly new forms of political action. Usually heralding a cascade of temporally compressed contentious events, these key events are both unique in their underlying dynamics and their transformative potential. Becoming part of the cultural stock of a movement, they also provide moral reference points and create new possibilities for framing. Thereby they can become resources for the formation of new subjectivities, for meaning-making, and - ultimately - for recruitment and backlash mobilization (Jasper \& Poulsen, 1995, p. 497f.; Olesen, 2009, p. 26).

Transformative events and the critical junctures they heralded played a vital role in the uprisings across the MENA region. Jillian Schwedler has argued that the initial acts of the uprisings - despite the idiosyncratic differences between the various cases of mass protest across the region - were akin in their symbolism and effect to the events described by Sewell: "Just 
as taking the Bastille helped transform the self-understandings of French subjects into citizens, the early days of the Arab uprisings were necessary to make imaginable actually thinkable" (Schwedler, 2016). When 26-year old Mohamed Bouazizi set himself aflame in the town of Sidi Bouzid on December 17, 2010, his self-immolation became a transformative event that "sparked the fire in millions like him" (Chatterji, 2013, p. 96). In the Egyptian case, in turn, the torture and the killing of the Alexandrian teenager Khaled Said by police officers in late 2010, became a transformative event (Della Porta, 2014a, p. 101). Not only was Khaled Said's portrait a recurrent image during all kinds of protests against state violence in 2011, but his murder also served as a trigger for a massive backlash that drove the number of young people who sympathized with Said's ordeal and were willing to show their solidarity by protesting to new heights.

What is more, the Arab Spring demonstrates the ability of such transformative events to impact even geographically distant sites. Khaled Said and Mohamed Bouazizi became icons not only in Egypt and Tunisia. Their images and corresponding narratives traveled across borders to enter the cultural stock of movements beyond the region. The new culture of resistance developed during the Tunisian and Egyptian uprisings easily connected to and fueled through its success story a globally shared desire for direct participation in politics (see El-Sharnouby, 2018b). Miniya Chatterji (2013, p. 101), for instance, has explored how the "dignity uprisings" in the Arab world served as transformative events for struggles in India, where they provided strength and legitimacy to the local anti-corruption movement. In a similar vein, Sarah Kerton (2012) has argued that the successful defense of the protest camps on Tahrir Square played a crucial role in initiating and shaping Europe's Occupy movement. Even long after protesters had emptied the square, the aura of Tahrir lasted on for European activists, influencing the forms of what was thinkable and possible in their spatial present.

When it comes to the aftermath of the Arab Spring, together with Cilja Harders (2018), I have explored the decisive impact of transformative events on the trajectory of contention in Egypt. We pointed out how they were recurrently followed by "moral shocks" (Jasper \& Poulsen, 1995, p. 498) which compelled formerly contention-averse people to take to the street in large numbers. Generated by blatant acts of state violence, these moral shocks raised such a sense of public outrage that individuals were mobilized, even in the absence of prior networks of recruitment, and although structural conditions were not ripe for protest. For this recurrent unintended consequence of state repression, Ronald Francisco (1995) has coined the term "backlash protest" (p. 263). The risk of backlash mobilization following repression 
is generally found to increase when repression is applied reactively and indiscriminately against all opponents regardless of their rank (Della Porta, 2014b, p. 169; Khawaja, 1993), instead of selectively targeting leading cadres of a movement or agents provocateurs, thus causing the individual costs of participating in a protest to approximate those of non-participation (M. Hafez, 2003; Mason \& Krane, 1989). Moreover, backlash becomes likely when the level of repression, that is, police brutality or the severity of restrictions, surpasses a certain threshold (Francisco, 2004).

Prominent examples referred to in the literature as transformative and highly mobilizing backlash events are the Bloody Sunday Massacre in Northern Ireland, or the Sharpeville Massacre in South Africa (Hess \& Martin, 2006, p. 251). In turn, during the January 25 Revolution, the vicious attempt by the Mubarak regime to disperse the crowds on Tahrir Square with the help of hired thugs on camelback was such a transformative event. The violent attack on February 2, 2011, recalled as the Battle of the Camel during the occupation of Tahrir, strengthened the determination of those defending the square and triggered massive backlash mobilization (Holmes, 2012, p. 399).

\section{Making Events Transformative}

Like during other confrontations on Tahrir Square, a range of complex emotional dynamics worked together to turn the Battle of the Camel into a transformative moment. Several observers have described how, before the attack, the Tahrir occupation had become a sort of protest carnival despite the massive risks and protesters' victimization by police forces (see Jasper, 2018; Ayata \& Harders, 2018; Said, 2015). They contend that the bodily copresence, joint practices, and collective performances during the prolonged occupation of Tahrir Square (and other squares in the region that witnessed large-scale occupations, such as Taksim Square in Istanbul or the Pearl Roundabout in Manama, Bahrain) led to the emergence of multi-layered affective dynamics. These included aspects of joy, excitement, and liberation and served to catalyze processes of solidarization. In their interplay, they "enabled outright antagonistic actors to protest together" (Ayata \& Harders, 2018, p. 116). But they were also key in sustaining resistance when the camps were attacked. As Jasper (2018) argues, "with that exhilaration as background, each attack - verbal or physical - by Mubarak's thugs and spokespersons created more indignation than fear. Or rather, indignation turned the reflex fear into a useful moral feeling of outrage" (p. 78 ). This 
moral outrage vitalized the protest movement, shored up its resilience, and contributed to a continuous influx of protesters until Mubarak resigned.

Violent events such as massacres have a particularly intense emotional impact on society. These encounters give rise to "intense emotions, such as excitement, and strengthened commitment to radical politics" (Della Porta, 2008, p. 172). However, moral outrage may also be triggered by different kinds of structural contradictions and implosions that disrupt players' perception of their lifeworld, thus eliciting an intense emotional response (Pearlman, 2013; Benski \& Langman, 2013; Benski et al., 2013). Large ruptures in the life cycle of social movements are easily recognizable, but small ruptures can be equally meaningful and indicate "a pushing of boundaries by defiance of a previously honored red line, whether done by the security services or by protesters" (Schwedler, 2018, p. 72). Disruptions of "the quotidian," that is, of the taken-for-granted routines and attitudes of everyday life, can be a highly productive force as regards mobilization.

A recently published volume, edited by Jim Jasper and Frederic Volpi (2018), explores the dynamics of meaning-making on a micro-level. Therein Schwedler (2018) convincingly argues for a closer study of protest events, not only as a component of a larger protest cycle which helps to piece together a larger study but especially in terms of the meaning that people attribute to them. Methodological nationalism and a macro focus on the larger protest waves or cycles, she contends, have led scholars to overlook the vital question of how meaning is generated by the actors involved in the protests themselves throughout even a single event: "What political work is done in the course of a protest or set of protests, and for and by whom?" (Schwedler, 2018, p. 71). Centering her analysis on the regularities and ruptures in the micro-practices of the "Kaluti protests" against the Israeli embassy in Jordan she shows how, at times, even small ruptures can become very meaningful events for collective actors. It is whether these events on the ground develop affective power and touch people's hearts and minds that decides if they inspire backlash or not.

Even when events involve violence, the creation of "myths and martyrs" (Della Porta, 2006, p. 161) is not an automatism. Shocking violence may sometimes become a "summary symbol" that intensifies the meaning of resistance (Cremer-Schäfer, 1992, p. 24). But often brutal violence also deters dissent and prevents the emergence of strong political players. Either outcome is highly dependent on the discursive embedding of events and how audiences make meaning of their feelings towards the events they witness by placing them in certain narratives over others. As Margaret Archer (2003) asserts, "courses of action are produced through the reflexive 
deliberations of agents who subjectively determine their practical projects in relation to their objective circumstance" (p.165). Even concrete physical experiences - the tear gas and batons of the police, the injustices suffered at the hands of the state, the strenuous resistance against an overwhelming deployment of security forces - must be embedded in symbolic structures to attribute a certain meaning to them

For instance, Youssef El Chazli (2018, p. 140ff.) has argued that the abuse and killing of Khaled Said in itself was not an extraordinary event. Torture and police brutality were commonplace in Mubarak's Egypt. Hence there was nothing inherently significant about Said's murder. What made it transformative was that several political players seized the event as a public case to define a political enemy. The murder of the Alexandrian teenager cleft a political chasm between Egypt's people and its police. Beyond the immediately suffered experience, the (re)construction of the event was thus imperative for subsequent mobilization (Della Porta, 2014b, p. 177).

In line with this reasoning, Colin Hay (1996, p. 424) has argued on a more general level that the effects of political crisis events are always dependent on their discursive mediation through narratives. Narratives can be understood as "the representation of an event or a sequence of events, real or fictitious, through thematically connected (as opposed to merely chronologically listed) words and images" (Jasper et al., 2020, p. 20). Crises and critical junctures are accessed in and through such narratives. The interaction between the state and contenders thus also takes place in the discursive arena, in addition to the material arena of the street where police forces shoot their tear gas canisters, and where demonstrators answer with stones and roadblocks (see Jasper \& Duyvendak, 2015). Emotionality and affect play an important role in this process. They help explain "why some symbols and meanings grab us and others leave us cold" (Jasper et al., 2020, p. 251), and thus, ultimately, the resonance of certain narratives over others. To subvert dominant codes, movements must construct compelling sets of representations that are not only convincing but also able to touch people's feelings.

Social movement scholars have attempted to capture this interpretive process in the concept of framing. According to this influential strand of research, diverging readings of demonstrators' physical interactions with, for instance, police forces emerge from the contested framing of events by the contending players. Framing works on discourse in a similar fashion as a frame around a picture does (Noakes \& Johnston, 2005, p. 2), concurrently highlighting and excluding certain items and features, establishing clearly what is to be taken as relevant in the artistic composition and what as redundant. In essence, framing implies two dimensions: First, it captures 
the cognitive process through which players make sense of the events they witness. Adding to this encoding of reality, framing embodies the discursive work by which actors communicate the meanings they attach to events (G. Brown, 2014, p. 143). The perceived causes of, reasons for, or solutions to certain events are thereby translated into specific symbolic structures and positioned within strategically manufactured narratives.

Yet how does this process influence the conditions for mobilization or repression? The framing perspective recognized social movements as signifying agents and no longer reduced them to carriers of extant ideas that are rooted in their structural positions (Benford \& Snow, 2000, p. 613). But it failed to conceptualize the link between players' discourses and their impact on the arenas of protest in a compelling way. Like in the opportunities approach, the prominence of some narratives over others is explained in purely structural terms: Depending on people's economic dispositions, their ideology, or their access to resources, movement narratives may end up stuck in dead-end streets or assume a favorable symbolic position and facilitate mobilization. By contrast, discourse theoretical approaches give the struggle over meaning as the constitutive element of the social center stage.

\section{A Discourse Theoretical Perspective on Contentious Politics}

At the foundation of discourse theory lies the assumption that society cannot be understood as a structured totality and cannot be described through any unifying principle. This does not mean that there is not some form of social order which structures daily life. There is just no necessary one. All social orders - just like social identities - are necessarily contingent. Ernesto Laclau and Chantal Mouffe (2001), who are commonly viewed as the founders of the so-called Essex School of discourse theory, call this the "constitutive openness" of the social (p. 96).

In their founding text, they contest the "lingering class essentialism" (Keucheyan \& Elliott, 2013, p. 240) of Marxist theory and defend an antiessentialist view of social struggles. The classical Marxist position had assumed that a subject's social position, despite its empirical variations and tendencies on the surface, could always be traced back to its position as a partial element in an essential social order. The social had been presented as "a structural totality with its own identifiable and intelligible positivity" (Hall, 1988, p. 43) enabling all those able to read the code that structured "the social" - that is, of course, the laws of capitalist production - to identify the position of all of society's elements. Ultimately, social players' role in 
politics was always defined by their position in the capitalist relations of productions. The working class was therefore ascribed with the natural role of the revolutionary subject and consequently the greatest hegemonic potential.

Against this backdrop, Gramsci's lifework constituted a turning point for Laclau and Mouffe (Laclau \& Mouffe, 2001, p. 67). His conception of hegemony replaced the static and often essentializing concept of ideology in Marxist thought. It enabled Gramsci to grasp the increasing significance of culture in social relations. For Gramsci, political subjects were not strictly speaking class subjects. Gramsci viewed political rule as more than a mere mirror image of material realities bound by inextricable economic laws. Instead, those in power constantly had to manufacture social consent and acquiescence for their rule through discursive processes of articulation (see Gramsci, 1971, pt. 2). Gramsci referred to this political logic as hegemony. It denotes the creation of consensus by persuasion and the enforcement of power asymmetries without resorting to force.

Gramsci's social theory maintained an essentialist core that tied hegemony to the naturalization of class divisions (Keucheyan \& Elliott, 2013, p. 240). As adopted by Laclau and Mouffe, however, hegemony describes the naturalization of all kinds of power relations, of which class is but one possible option. In a world that is radically heterogeneous, fragmented, and volatile, they argue, social identity is anything but defined a priori. ${ }^{3}$ Instead, the coherence of social players is highly contingent on (and constructed by) the dynamics of a struggle (Shantz, 200o, p. 92f.). In this sense, social life had to be interpreted as a continually shifting surface of inscription of a variety of meanings.

Building on this though, Laclau and Mouffe suggest conceiving the social as a hegemonic terrain. This terrain finds its expression in the strategic interactionist notion of a discursive arena. In it, many players attempt to convince others of their reading of social reality to widen their room for maneuver. In protest arenas, the competitive nature of this discursive layer is evident. As part of their power struggle, contenders constantly assign

3 Their deconstruction of historical materialism built on the empirical observation that the social world has become more complex than forecast by Marxism. Far from consolidating, class cleavages have become ambiguous and supplemented by other layers of identity. This cast doubts on workers' objectively antagonist relationship to capital and on the link between structural positions and the constitution of interests. Rather than the workers assuming their revolutionary role, researchers were witnessing the emergence of new social movements who no longer focused exclusively on economic demands and whose mobilizing structures and resources were not organized along class divides. 
protest and repression events with competing meanings to claim moral authority and garner support: police forces vilify demonstrators to undercut their social base and legitimize repression; demonstrators expose state violence to trigger reflex emotions and elicit sympathy and action from other political players (see Jasper, 2018, p. 55). They often represent social reality in mutually exclusive ways. These constructions have consequences for the trajectory of contentious politics. They give the social a specific form that may allow or prevent certain courses of action.

The most significant consequence of this constitutive openness of the social is the realization that the meaning of objects, including contentious phenomena such as protests, cannot be objectively determined. According to Hay (2013), events are "what we make of them; and what we make of them determines how we respond" (p. 23). Discourse analyses thus cannot aim to discover the truth about social reality. Instead, they can only describe how the discursive interactions of social players construct this reality "so that it appears natural and neutral" (Rear, 2013, p. 5) and in line with common sense. This construction occurs through strategic acts of articulation by social players in different arenas of struggle. ${ }^{4}$ Laclau and Mouffe (2001) define the essential dimensions of this process of meaning-making as follows:

We will call articulation any practice establishing a relation among elements such that their identity is modified as a result of the articulatory practice. The structured totality resulting from the articulatory practice, we will call discourse. The differential positions, insofar as they appear articulated within a discourse, we will call moments. By contrast, we will call element any difference that is not discursively articulated. (p. 105)

Underlying their conception of discourse is the notion of a discursive field consisting of a multitude of signifiers. None of these signifiers themselves are fixed to a particular signified. Their identity stems from the discourse in which it is located. This makes them open to different meaning ascriptions (Torfing, 1999, pp. 98-99). Through their messages, slogans, and communicative practices, different players attempt to fix a web of meanings within a particular domain by structuring these signifiers into meaningful relations to the exclusion of others.

We can thus imagine discourses as webs of multiple "floating" elements that are interconnected through players' articulations. In these discourses,

4 For an overview glossary of Laclau and Mouffe's specific terminology, see Table 3 in the Appendix. 
different elements are grouped around nodal points, eminent signifiers that structure the discursive field (Laclau \& Mouffe, 2001, p. 112). According to Jørgensen and Phillips (2002), a nodal point is "a privileged sign around which the other signs are ordered; the other signs acquire their meaning from their relationship to the nodal point" (p. 26). A popular example of such a nodal point is the signifier "people" within populist discourses (Laclau, 2005, p. 153). From this nodal signifier, technical terms such as "border," but also terms with multi-layered meanings such as "nation" or "elite," derive their specific meaning. The practice of articulation ultimately consists in the construction of relational webs of meaning around such nodal points.

The relation by which elements are linked can be one of difference or equivalence (Laclau, 2005, p. 78). It is at the level of these relations that the crucial contests over meaning take place. For instance, police forces often place small-scale melees with demonstrators, the destruction of property during protests, and large-scale riots into a relation of equivalence through their common definition as protester violence. By contrast, within social movement discourses, these phenomena may assume differential positions when they are framed either as self-defense, as a disruption of the capitalist means of production, or as legitimate resistance against structural oppression, respectively. These clashing interpretations represent the points of crystallization lines along which collective identities are developed and the fault lines along which political actors can rally support.

\section{Disruptive Events and the Articulation of Antagonism}

Processes of political subjectivation are usually triggered by disruptive events that challenge established knowledge and open up opportunities for new political rationalities to evolve (see Nabers, 2017). As Schwedler (2016) underscored, a single event "can fundamentally transform the horizon of what people believe is possible" and thus enable new articulatory projects. For those participating in or witnessing them, these events reveal their transformative character by significantly disrupting, altering, or violating the taken-for-granted assumptions governing routine political and social relations. Laclau and Mouffe refer to these ruptures as "dislocations" (Laclau and Mouffe 2001, 49f.; Laclau 1990, 41ff.).

Dislocation, according to the authors, describes the need for the re-arrangement of discourses to incorporate new events. It is caused by those events that cannot immediately be incorporated into the current horizon of expectations. That is, those events that cannot be symbolized or made sense of within the prevailing discourse, or as Marchart (2014) states, they are "something we 
did not expect and which therefore threatens the sedimented routines and processes of social institutions" (p. 277). By uprooting the sedimented meaning of nodal signifiers, these events reveal the contingency of the social order.

For contentious politics, such ruptures can be a productive force. By shattering interpretations of social reality that had gone unquestioned they create possibilities for activists to renegotiate the limits of what is thinkable, in terms of political alternatives, and doable, in terms of actions on the ground. Colin Hay (1996), who has produced some of the most insightful works on the effects of political crises, has therefore described critical junctures that lay bare the precariousness of the social order as moments of decisive intervention. These interventions can take different directions. They can reify existing power relations, such as, after the September 11 attacks, when the widespread impression that the United States was experiencing a liminal moment streamlined mainstream discourses and closed the space for alternative interpretations (see Bail, 2012). But they can also challenge the status quo. It is usually in moments of dislocation when processes of disidentification with the prevailing order and those that sustain it begin. Contenders can react to this crisis by attempting to "hegemonize the gap" (Nabers, 2017, p. 422) and by forging resistance around political alternatives.

From the perspective of discourse theory, this resistance operates according to relational rules of subject formation - the We is defined vis-à-vis the Other. It is this differential relation to a constitutive outside (who I am not) that confirms and fixates social identity (who I am). ${ }^{5}$ According to Laclau (2006), to constitute a popular political subjectivity a player "has to discursively construct the enemy - the oligarchy, the establishment, big money, capitalism, globalization" (p. 655). If manifold sectors of society join a protest movement in rejection of government policy, this is made possible not by their mutual solidarity based on their common adherence to the same class, gender, etc., but by their common rejection of the constructed other - in many cases the government. In the absence of any pre-discursive features uniting them, the mobilized populace has at least one thing in common: the antagonism between their subject position and that of their adversary.

5 Laclau and Mouffe draw on Georges Sorel's conception of a world based on the primacy of conflict. However, unlike Sorel they do not see this conflict as one that follows any essential qualities or pre-discursive features of the social. For instance, class struggles are but one of many articulations of social antagonism. This rigorous abandonment of a class perspective finds its correlate in the notion of ubiquitous antagonisms as constitutive features of subject formation: if "no 'essence' underlies the social, the entities that develop in it are necessarily relational - that is to say, they are constructed with respect to one another or against one another" (Keucheyan \& Elliott, 2013, p. 241). 
In framing approaches to social movement studies this differential process has been captured in the concepts of "boundary framing" and "adversarial framing" (Benford \& Snow, 2000, p. 616; see also Hunt et al., 1994), attributional processes that construct and delineate between movement protagonists and antagonists. This construction process cuts across different dimensions of the framing process: Players usually adopt a diagnostic frame when they portray their political antagonists. Through this act of naming and shaming, they define the problem and appoint responsibility. By contrast, their self-portrayal usually reproduces a prognostic frame by designating who should act, and how. Moreover, antagonizing narratives usually involve an additional motivational component that aims to justify action against the designated enemy. The motivational frame typically stresses urgency and a duty to act. It often adds a moral dimension to the hitherto rational line of argument (Noakes \& Johnston, 2005, p. 2). Appeals to tradition, values, and belief systems target the emotional drivers of a movement's audience. In sum, there are, at least, three antagonisms that pervade the communications of protest players and can be investigated through discourse analyses:

1 one that pits the agents of injustice against their victim, and the agents of change,

2 one that contrasts the deeds of the former with the demands and strategies of the latter as a plan to solve an impasse or crisis,

3 and one that juxtaposes the moral superiority of the collective subject with the moral corruption of the antagonists other.

Each of these levels is equally important for the cohesion and recruitment of a social movement and thus for processes of collective identity formation. James Jasper, Michael Young, and Elke Zuern have dedicated an entire book to exploring how social groups build solidarities, policies, and social movements out of such clear-cut divisions - admiration for heroes and outrage for villains - that require diligent character work (Jasper et al., 2020, p. 2).

The emergence of a positive collective subject, such as a social movement, is achieved by the articulation of a link between its elements that is not shared by the enemy. This chain of equivalence dissolves the differential relations among the individual movement components through common reference to an external other. The specificity of their demands dissolves once they meet with rejection from a common enemy, paving the way for alliance-building and collective identity formation (Keucheyan \& Elliott, 2013, p. 242). The logic of difference that previously defined their interrelation 
is functionally replaced by a logic of equivalence; sectoral particularisms are transformed into a collective rejection of an antagonist other.

This process was illustrated by the Arab Spring: Part of the recipe for the success of the 2011 mass protests was their rejection of a unitary ideology and their dissolution of social differences in an equivalential chain of demands, with "neither a unitary subject to act as a signifier nor any metanarrative to contain its message" (Hale, 2014). The emergence of such a compound player resisting the status quo represented a subjectivation process that related different individuals to what Farhad Khosrokhavar (2018) has referred to as a "would-be social movement" (p. 163). A subsequent affective process of emotional affiliation, termed the "Midan Moment" by Ayata and Harders (2018), forged the multiple elements into a unified struggle:

In the Egyptian Revolution, the loose association of individuals with disparate social conditions gave birth to collective action against the Mubarak regime. This was made possible through 'subjectivation': the latter compensated for the heterogeneous conditions of the people, creating a unity of emotions autonomous from their "objective" social conditions (Khosrokhavar, 2018, p. 163).

This subjectivation was paralleled and reinforced by a dichotomization of the political spectrum into two antagonist camps, as the revolutionaries from different class backgrounds and conflicting ideologies found solidarity in their shared rejection of the Mubarakist state (see Smaldone, 2015). The iconic slogan "al-sha'ab yurid isqat al-nizam" [the people want the fall of the regime] evidences this antagonist formation (see Svendsen, 2014, p. 46). It articulates a commonality between all those taking to the streets and establishes the regime and its stooges as the main obstacles for transformation. Laclau (2005) describes this as the emergence of an "internal frontier, a dichotomization of the local political spectrum through the emergence of an equivalential chain of unsatisfied demands" (p. 74). This antagonist frontier separates the people from power, enabling a plurality of demands to constitute a broader social subjectivity.

\section{Synthesis}

Meanings are not produced in a vacuum but through sharing and exchange of argument. And they are both realized through and respond to interaction. Analyses must account for how discourses are produced and engaged within a framework of understanding that is being shaped through broader 
processes of social interaction. Unfolding events leave traces in contenders' discourses and contribute to the emergence, permutation, and demise of political subjectivities. Vice-versa, discourses come to constitute and redefine social reality by altering conditions of possibilities for action. Cultural interactionist frameworks of analysis are suited to capture these dynamics by conceptualizing the relation between social players and the social arenas in which they interact as a two-way street. This makes it possible to conceive of the interactions among the main contenders in Egypt's post-coup theater as contingent reactions to a series of critical junctures and, at the same time, as constitutive practices that turned these junctures into transformative events, reshaped parameters of the political game, and gave rise to antagonist struggles over meaning.

Laclau and Mouffe's concept of dislocation aptly captures the discursive character of those events that social movement scholars have referred to as transformative, precipitating, or turning point events. As Nabers (2017) recapitulates:

These "events" are never situated outside of a discourse. They neither have a temporal nor a spatial location outside of the discursive frame that translates it from a "pure event" - with all its ambiguities, displacements, and disruptions - into a "historical event" (p. 425).

It is the way how activists articulate their meaning and how they weave them into counter-hegemonic narratives that provides these events with a transformative character. This process generates texts, speeches, and other products of articulatory practices which can be collected as "snapshots" of certain players' discourses at a specific point of time and analyzed in relation to the social situation they are inserted. It also implies agency: In analogy to the study of protest performances, discourse is viewed as an iterative process, constituted by countless acts of articulation on the part of the contending players. Through these interactions, the latter can create opportunities for themselves and other players, but also influence the trajectory of unfolding events. According to Hay (2013, p. 425), the collective mobilization of popular perceptions at moments of crisis is crucial in influencing the trajectory of contentious dynamics. They open or foreclose windows for mobilization, provide fertile ground for, or impede the emergence of new political alliances, and bridge or reify preexisting social and ideological cleavages.

Discourse theory provides the analytical vocabulary for describing the process by which antagonisms are constructed in this process; how chains of equivalence are established that delineate between those who are part of 
a movement and those who are not; and how differences among different players are moderated by a common relation to central signifiers. In turn, framing approaches point out those layers of social movement discourses where political subjectivation processes can sensibly be analyzed. Through the coaction of these layers, signifying players supply both the We who should act collectively as an agent of change and the antagonist Other who should be acted against. Thereby, the discursive space is dichotomized, between those who are part or allies of the movement and those who are not.

Establishing clear-cut antagonisms on all three levels can help mobilize people and their passions and forge strong alliances between political players. At the same time, as will be shown in later chapters of this book, these antagonisms may also constrain players' actions. Jasper and his collaborators underscored a dilemma also faced by the Egyptian Muslim Brotherhood after becoming the target of state repression: "If you have demonized your opponent as malevolent and unreliable, it may be hard for you to justify negotiations with them" (Jasper et al., 2020, p. 9).

As the remaining chapters of this book illustrate, thinking of the interpretive battles after key events as a contentious struggle at the level of individual signifiers, between dynamic players in a changing discursive arena allows for an analysis of contentious politics that transcends the structural determinism of classical discourse theoretical approaches and reconstructs contenders' identities in more nuanced ways, and in relation to the dynamics of their struggle.

\section{References}

Abdalla, K. (2016). Changing frames and fault-lines. In M. Baker (Ed.), Translating dissent: Voices from and with the Egyptian Revolution (pp. 33-44). Routledge.

Alimi, E. Y., \& Meyer, D. S. (2011). Seasons of change: Arab Spring and political opportunities. Swiss Political Science Review, 17(4), 475-479. https://doi.org/10.1111/j.1662-6370.2011.02041.x

Archer, M. S. (2003). Structure, agency and the internal conversation. Cambridge University Press.

Ayata, B., \& Harders, C. (2018). Midān moments: Conceptualizing space, affect and political participation on occupied squares. In B. Röttger-Rössler \& J. Slaby (Eds.), Affect in relation: Families, places and technologies (pp. 115-133). Routledge.

Bail, C. A. (2012). The fringe effect: Civil society organizations and the evolution of media discourse about Islam since the September 11th attacks. American Sociological Review, 77 (6), 855-879. https://doi.org/10.1177/0003122412465743

Beissinger, M. R. (2009). Nationalism and the collapse of Soviet Communism. Contemporary European History, 18(3), 331-347.

Benford, R. D., \& Snow, D. A. (2000). Framing processes and social movements: An overview and assessment. Annual Review of Sociology, 26, 611-639. 
Benski, T., \& Langman, L. (2013). The effects of affects: The place of emotions in the mobilizations of 2011: Current Sociology. https://doi.org/10.1177/0011392113479751

Benski, T., Langman, L., Perugorría, I., \& Tejerina, B. (2013). From the streets and squares to social movement studies: What have we learned? Current Sociology, 6r(4), 541-561. https:// doi.org/10.1177/0011392113479753

Blumer, H. (2009). Symbolic interactionism: Perspective and method. University of California Press.

Bourdieu, P. (1987). What makes a social class? On the theoretical and practical existence of groups. Berkeley Journal of Sociology, 32, 1-17.

Bourdieu, P. (1993). The field of cultural production (R. Johnson, Ed.). Columbia University Press.

Brown, G. (2014). Does framing matter? Institutional constraints on framing in two cases of intrastate violence. Mobilization, 19(2), 143-164. https://doi.org/10.17813/maiq.19.2.j13338h544l20720

Chatterji, M. (2013). The globalization of politics: From Egypt to India. Social Movement Studies, 12(1), 96-102. https://doi.org/10.1080/14742837.2012.698132

Cremer-Schäfer, H. (1992). Skandalisierungsfallen. Einige Anmerkungen dazu, welche Folgen es hat, wenn wir das Vokabular 'der Gewalt' benutzen, um auf gesellschaftliche Probleme und Konflikte aufmerksam zu machen. Kriminologisches Journal, 24(1), 23-36.

Della Porta, D. (2006). Social movements, political violence, and the state. Cambridge University Press.

Della Porta, D. (2008). Eventful protest, global conflicts. Distinktion, 9(2), 27-56.

Della Porta, D. (2011). Eventful protest, global conflicts: Social mechanisms in the reproduction of protest. In J. M. Jasper \& J. Goodwin (Eds.), Contention in context: Political opportunities and the emergence of protest (pp. 256-276). Stanford University Press.

Della Porta, D. (2014a). Mobilizing for democracy: Comparing 1989 and 2011. Oxford University Press.

Della Porta, D. (2014b). On violence and repression: A relational approach (the Leonard Schapiro memorial lecture, 2013). Government and Opposition, 49(2), 159-187. https://doi.org/10.1017/ gov.2013.47

Della Porta, D., \& Atak, K. (2017). The spirit of Gezi: A relational approach to eventful protest and its challenges. In Global diffusion of protest: Riding the protest wave in the neoliberal crisis (pp. 31-58). Amsterdam University Press. https://doi.org/10.1515/9789048531356-003

DiMaggio, P. J., \& Powell, W. W. (1983). The iron cage revisited: Institutional isomorphism and collective rationality in organizational fields. American Sociological Review, 48(2), 147-160. https://doi.org/10.2307/2095101

Duyvendak, J. W., \& Jasper, J. M. (Eds.). (2015). Breaking down the state: Protestors engaged. Amsterdam University Press.

Earl, J., \& Soule, S. A. (2010). The impacts of repression: The effect of police presence and action on subsequent protest rates. In P. G. Coy (Ed.), Research in social movements, conflicts and change (pp. 75-113). Emerald Group Publishing Limited.

El Chazli, Y. (2018). It takes two (or more) to tango. In F. Volpi \& J. M. Jasper (Eds.), Microfoundations of the Arab uprisings: Mapping interactions between regimes and protesters (pp. 135-158). Amsterdam University Press.

El-Sharnouby, D. (2018). New social movements: The case of youth's political project in Egypt. Middle East Law and Governance, $10(3)$, 264-29o. https://doi.org/10.1163/18763375-01003003

Fligstein, N., \& McAdam, D. (2015). A theory of fields (First issued as an Oxford University Press paperback). Oxford University Press.

Francisco, R. A. (1995). The relationship between coercion and protest: An empirical evaluation in three coercive states. The Journal of Conflict Resolution, 39(2), 263-282.

Francisco, R. A. (2004). After the massacre: Mobilization in the wake of harsh repression. Mobilization: An International Quarterly, 9(2), 107-126. 
Giugni, M. (2009). Political opportunities: From Tilly to Tilly. Swiss Political Science Review, 15(2), 361-367. https://doi.org/10.1002/j.1662-6370.2009.tboo136.x

Goffman, E. (1986). Strategic interaction (3rd ed.). University of Pennsylvania Press.

Goodwin, J., Jasper, J. M., \& Khattra, J. (1999). Caught in a winding, snarling vine: The structural bias of political process theory. Sociological Forum, 14(1), 27-54.

Gramsci, A. (1971). Selections from prison notebooks. Lawrence and Wishart.

Grimm, J.J., \& Harders, C. (2018). Unpacking the effects of repression: The evolution of Islamist repertoires of contention in Egypt after the fall of President Morsi. Social Movement Studies, 17(1), 1-18. https://doi.org/10.1080/14742837.2017.1344547

Hafez, M. (2003). Why Muslims rebel: Repression and resistance in the Islamic world. Lynne Rienner Publishers.

Hale, S. (2014). The new Middle East insurrections and other subversions of the modernist frame. Journal of Middle East Women's Studies, 10(3), 40-61. https://doi.org/10.2979/ jmiddeastwomstud.10.3.40

Hall, S. (1988). The toad in the garden: Thatcherism among the theorists. In C. Nelson \& L. Grossberg (Eds.), Marxism and the interpretation of culture (pp. 35-57). Macmillan Education UK.

Harders, C., \& König, C. (2013). Mobilization, repression and coalitions: Understanding the dynamics of the Arab Spring [Discussion Paper]. Center for Middle Eastern and North African Politics. https://www.polsoz.fu-berlin.de/polwiss/forschung/international/vorderer-orient/publikation/working_papers/dp_o6/index.html

Hay, C. (1996). From crisis to catastrophe? The ecological pathologies of the liberal - democratic state form. Innovation: The European Journal of Social Science Research, 9(4), 421-434. https:// doi.org/10.1080/13511610.1996.9968500

Hay, C. (2013). Treating the symptom not the condition: Crisis definition, deficit reduction and the search for a new British growth model. The British Journal of Politics \& International Relations, 15(1), 23-37. https://doi.org/10.1111/j.1467-856X.2012.00515.X

Hess, D., \& Martin, B. (2006). Repression, backfire, and the theory of transformative events. Mobilization, $11(2)$, 249-267.

Holmes, A. A. (2012). There are weeks when decades happen: Structure and strategy in the Egyptian revolution. Mobilization, 17(4), 391-410. https://doi.org/10.17813/maiq.17.4.905210228n564037

Hunt, S. A., Benford, R. D., \& Snow, D. A. (1994). Identity fields: Framing processes and the social construction of movement identities. In E. Laraña, H. Johnston, \& J. R. Gusfield (Eds.), New social movements: From ideology to identity (pp. 185-208). Temple University Press.

Jasper, J. M. (2008). Getting your way: Strategic dilemmas in the real world. University of Chicago Press.

Jasper, J. M. (2015a). Introduction: Players and arenas formerly known as the state. In J. M. Jasper \& J. W. Duyvendak (Eds.), Breaking down the state: Protestors engaged (pp. 9-24). Amsterdam University Press. https://doi.org/10.2307/j.ctt196315k.3

Jasper, J. M. (2015b). Introduction: Playing the game. In J. M. Jasper \& J. W. Duyvendak (Eds.), Players and arenas: The interactive dynamics of protest (pp. 9-32). Amsterdam University Press. https://doi.org/10.2307/j.ctt16vj285.3

Jasper, J. M. (2018). The emotions of protest. The University of Chicago Press.

Jasper, J. M., \& Duyvendak, J. W. (Eds.). (2015). Players and arenas: The interactive dynamics of protest. Amsterdam University Press.

Jasper, J. M., \& Poulsen, J. D. (1995). Recruiting strangers and friends: Moral shocks and social networks in animal rights and anti-nuclear protests. Social Problems, 42(4), 493-512. https:// doi.org/10.2307/3097043 
Jasper, J. M., \& Volpi, F. (2018). Introduction: Rethinking mobilization after the Arab uprisings. In F. Volpi \& J. M. Jasper (Eds.), Microfoundations of the Arab uprisings: Mapping interactions between regimes and protesters (pp. 11-40). Amsterdam University Press.

Jasper, J. M., Young, M. P., \& Zuern, E. (2020). Public characters: The politics of reputation and blame. Jørgensen, M., \& Phillips, L. (2002). Discourse analysis as theory and method. Sage.

Kerton, S. (2012). Tahrir, here? The influence of the Arab uprisings on the emergence of Occupy. Social Movement Studies, n1(3-4), 302-308. https://doi.org/10.1080/14742837.2012.704183

Keucheyan, R., \& Elliott, G. (2013). Left hemisphere: Mapping critical theory today (2nd ed.). Verso.

Khawaja, M. (1993). Repression and popular collective action: Evidence from the West Bank. Sociological Forum, 8(1), 47-71.

Khosrokhavar, F. (2018). Violence, social actors, and subjectivation in the Egyptian revolution. In F. Volpi \& J. M. Jasper (Eds.), Microfoundations of the Arab uprisings: Mapping interactions between regimes and protesters (pp. 159-182). Amsterdam University Press.

Koopmans, R., \& Olzak, S. (2004). Discursive opportunities and the evolution of right-wing violence in Germany. American Journal of Sociology, no(1), 198-230. https://doi.org/10.1086/386271

Kriesi, H. (2004). Political context and opportunity. In D. A. Snow, S. A. Soule, \& H. Kriesi (Eds.), The Blackwell Companion to Social Movements (pp. 67-9o). Blackwell.

Laclau, E. (1990). New reflections on the revolution of our time. Verso.

Laclau, E. (2005). On populist reason. Verso.

Laclau, E. (2006). Why constructing a people is the main task of radical politics. Critical Inquiry, 32(4), 646-68o. https://doi.org/10.1086/508086

Laclau, E., \& Mouffe, C. (2001). Hegemony and socialist strategy: Towards a radical democratic politics (2nd edition). Verso.

Lawson, G. (2016). Within and beyond the "fourth generation" of revolutionary theory. Sociological Theory, 34(2), 106-127. https://doi.org/10.1177/0735275116649221

Marchart, O. (2014). Institution and dislocation: Philosophical roots of Laclau's discourse theory of space and antagonism. Distinktion:Journal of Social Theory, 15(3), 271-282. https://doi.org /10.1080/1600910X.2014.966272

Martin, J. L. (2003). What is field theory? American Journal of Sociology, $109(1)$, 1-49. https://doi. org/10.1086/375201

Mason, T. D., \& Krane, D. A. (1989). The political economy of death squads: Toward a theory of the impact of state-sanctioned terror. International Studies Quarterly, 33(2), 175-198. https:// doi.org/10.2307/2600536

McAdam, D., \& Sewell, W. H. (2001). It's about time: Temporality in the study of social movements and revolutions. In R. Aminzade, D. McAdam, E. Perry, W. H. Sewell, S. Tarrow, \& C. Tilly (Eds.), Silence and voice in the study of contentious politics (pp. 89-125). Cambridge University Press.

McCarthy, J. D., \& McPhail, C. (2005). Protest mobilization, protest repression, and their interaction. In C. Davenport, H. Johnston, \& C. Mueller (Eds.), Repression and mobilization (pp. 3-32). University of Minnesota Press.

McGarry, A., Davidson, R. J., Accornero, G., Jasper, J. M., \& Duyvendak, J. W. (2016). Players and arenas: Strategic interactionism in social movements studies. Social Movement Studies, 15(6), 634-642. https://doi.org/10.1080/14742837.2016.1199320

Nabers, D. (2017). Crisis as dislocation in global politics. Politics, 37(4), 418-431. https://doi. org/10.1177/0263395716661341

Noakes, J. A., \& Johnston, H. (2005). Frames of protest: A road map to a perspective. In H. Johnston \& J. A. Noakes (Eds.), Frames of protest: Social movements and the framing perspective (pp. 1-29). Rowman \& Littlefield Publishers.

Olesen, T. (2009). Social movement theory and radical Islamic activism. In Islamism as social movement (pp. 7-33). CIR Aarhus Universität. 
Pearlman, W. (2013). Emotions and the microfoundations of the Arab Uprisings. Perspectives on Politics, 11(2), 387-409. https://doi.org/10.1017/S1537592713001072

Polletta, F., \& Kretschmer, K. (2015). Movement factions: Players and processes. In J. M. Jasper \& J. W. Duyvendak (Eds.), Players and arenas: The interactive dynamics of protest (pp. 35-54). Amsterdam University Press. https://doi.org/10.2307/j.ctt16vj285.4

Pratt, N. (2015). After the 25 January Revolution: Democracy or authoritarianism in Egypt? In R. Abou-el-Fadl (Ed.), Revolutionary Egypt: Connecting domestic and international struggles. Routledge.

Rear, D. (2013). Laclau and Mouffe's discourse theory and Fairclough's critical discourse analysis: An introduction and comparison. Critical Policy Studies, 7(4), 375-394.

Rear, D., \& Jones, A. (2013). Discursive struggle and contested signifiers in the arenas of education policy and work skills in Japan. Critical Policy Studies, 7(4), 375-394. https://doi.org/10.1080 /19460171.2013.843469

Said, A. (2015). We ought to be here: Historicizing space and mobilization in Tahrir Square. International Sociology, 3o(4), 348-366.

Schwedler, J. (2016). Taking time seriously: Temporality and the Arab uprisings. Project on Middle East Political Science. https://pomeps.org/2016/06/1o/taking-time-seriously-temporalityand-the-arab-uprisings/

Schwedler, J. (2018). Routines and ruptures in anti-Israeli protests in Jordan. In F. Volpi \& J. M. Jasper (Eds.), Microfoundations of the Arab uprisings: Mapping interactions between regimes and protesters (pp. 67-88). Amsterdam University Press.

Schwedler, J., \& Harris, K. (2016). What is activism? Middle East Report, 281, 2-5.

Sewell, W. H. (1996). Historical events as transformations of structures: Inventing revolution at the Bastille. Theory and Society, 25(6), 841-881. https://doi.org/10.1007/BFoo159818

Sewell, W. H. (2009). Logics of history: Social theory and social transformation. University of Chicago Press.

Shantz, J. (2000). A post-Sorelian theory of social movement unity: Social myth reconfigured in the work of Laclau and Mouffe. Dialectical Anthropology, 25(1), 89-108.

Smaldone, T. (2015). The Arab uprisings and the blossoming of a 'global imaginary'. Inquiries Journal, $7(6), 1-3$.

Svendsen, K. D. (2014). The articulation of resistance and the Arab 'Spring': A post-structuralist perspective [Thesis in global studies]. Roskilde University.

Tarrow, S. (2001). Silence and voice in the study of contentious politics: Introduction. In R. Aminzade, D. McAdam, E. Perry, W. H. Sewell, S. G. Tarrow, \& C. Tilly (Eds.), Silence and voice in the study of contentious politics (pp. 1-10). Cambridge University Press.

Torfing, J. (1999). New theories of discourse: Laclau, Mouffe, and Ž ižek. Blackwell Publishers.

Volpi, F., \& Clark, J. A. (2019). Activism in the Middle East and North Africa in times of upheaval: Social networks' actions and interactions. Social Movement Studies, $18(1)$, 1-16. https://doi.or g/10.1080/14742837.2018.1538876

Volpi, F., \& Jasper, J. M. (Eds.). (2018). Microfoundations of the Arab uprisings: Mapping interactions between regimes and protesters. Amsterdam University Press.

Wacquant, L. J. D. (2019). Making class: The middle class(es) in social theory and social structure. In S. G. McNall (Ed.), Bringing class back in: Contemporary and historical perspectives. Routledge. https://doi.org/10.4324/9780429033612

Weipert-Fenner, I. (2021). Go local, go global: Studying popular protests in the MENA post-2011. Mediterranean Politics. 
